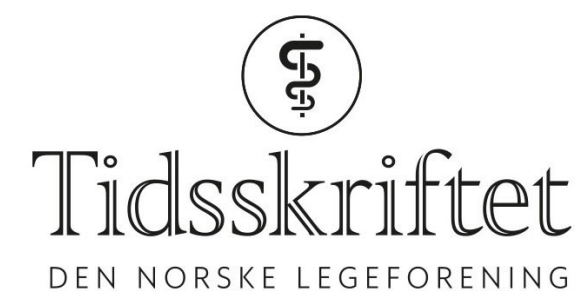

\title{
Rettelse: Behandling som begrenser multippel sklerose
}

RETTELSE

TRYGVE HOLMØY

GRO OWREN NYGAARD

KJELL-MORTEN MYHR

LARS B $\varnothing$

Tidsskr Nor Legeforen 2021; 141: 723-6.

I Tidsskriftet nr. 8/2021, s. 724 skal det i tabellhodet i Tabell 1 stå: Reduksjon av attakker i fase III-studier (6), Administrasjon (6), Egnet ved barneønske (7,8), Betydningsfull reduksjon av vasksineresponser (9).

Videre skal det i raden Okrelizumab stå: 46-47\% vs. interferon beta.

Det skal også stå i raden Ofatumumab: RRMS.

Vi beklager feilen, den er rettet på nett.

Publisert: 10. juni 2021. Tidsskr Nor Legeforen. DOI:10.4045/tidsskr.21.0454

(C) Tidsskrift for Den norske legeforening 2020. Lastet ned fra tidsskriftet.no 